\title{
THE ROLE OF HRM IN ENHANCING FINANCIAL INCLUSION IN INDIA BANKING SECTOR
}

\author{
Dr. Moath Mahmoud Alshar ${ }^{1}$, Dr. M. Sathya Shivalini ${ }^{2}$ \\ Business Management/ Osmania University, India
}

Article DOI: https://doi.org/10.36713/epra9442

DOI No: 10.36713/epra9442

\begin{abstract}
The main objective of current paper is identify the important roles of human resource management in enhancing the financial inclusion in Indian banking sector. The employees with reference to the roles of human resource management in Indian banking sector represented by the five banks is studied in this paper. The study population consisted of all employees in five Indian banks. A questionnaire was drafted and mailed to the one hundred and fifty employees randomly selected from the list of employees working for those banks. Fifty of the one hundred and fifty employees properly filled and the questionnaires and this is the main data source for my study. To achieve the objectives of the study, "to investigate into any relationship between Age, Gender and Educational level (demographic variable) of the employees and their impact on financial inclusion enhancement due to HRM roles" the researcher used descriptive analytical methods. The data was analyzed by employing One-way ANOVA test at 5\% level of significance using SPSS statistical software. The result showed that, the Indian banks employees strongly conformed the roles of human resource management in enhancing financial inclusion.
\end{abstract}

KEYWORDS: Human Resource Management (HRM), Financial Inclusion, Indian banking sector.

\section{INTRODUCTION}

A strong and efficient financial system helps in the economic development of the economy and raises the living standard of the people. It provides impetus to the weaker sections of the society by providing inputs and services through banks and other financial institutions thus helping them in making a better and more informed financial decision, which thus increases the participation of the masses in the economic development of a country. If there is increasing participation in financial development, better and wide access to the services helps in sustaining the development of an individual and thus an economy also.

A strong financial system plays a multidimensional vital role in the economic development of a country. In addition, it encourages savings and investments from different sectors of the economy; on the other hand, it plays a link between savers and investors by facilitating financial markets expansion and by providing aid in financial deepening and broadening.

The primary role of a robust financial system is "to provide a link between savings and investment for the creation of wealth and to permit portfolio adjustment in the composition of existing wealth".
The current study focuses on the pivotal role that human resources management can play in enhancing financial inclusion through bank employees. This is based on the importance of the organization's human resources for innovation and development to reach the highest level of effectiveness and effectiveness.

\section{FINANCIAL INCLUSION}

Financial inclusion is a necessity for a country where a large chunk of the world's poor resides. Access to finance by the poor and vulnerable groups is a prerequisite for poverty reduction, employment, economic growth, and social cohesion. Further access to finance will empower the vulnerable groups by giving them an opportunity to have a bank account, to save and invest, to ensure their homes, or to avail credit and facilitate them to break the chain of poverty.

Financial inclusion refers to a process that ensures the ease of access, availability and usage of the formal financial system for all members of an economy. An inclusive financial system has several merits. It facilitates efficient allocation of productive resources and thus can potentially reduce the cost of capital. In addition, access to appropriate financial 
services can significantly improve the day-to-day management of finances. An inclusive financial system can help in reducing the growth of informal sources of credit. Thus, an all-inclusive financial system enhances efficiency and welfare by providing avenues for secure and safe saving practices and by facilitating a whole range of efficient financial services.

Financial inclusion potential that people and corporations have get admission to beneficial and less costly monetary merchandise and offerings that meet their desires - transactions, payments, savings, deposit and insurance plan - delivered in a accountable and sustainable way.

Financial inclusion is the technique of making sure get entry to economic merchandise and offerings wanted through inclined organizations at a less expensive fee in an obvious manner via institutional players.

\section{HUMAN RESOURCE MANAGEMENT (HRM)}

Is the process of using people, coaching them, compensating them, growing policies referring to them, and growing techniques to preserve them. As a field, HRM has undergone many modifications over the ultimate twenty years, giving it an even greater vital function in today's organizations. In the past, HRM supposed processing payroll, sending birthday items to employees, arranging organization outings, and making certain varieties have been stuffed out correctly_in different words, greater of an administrative position as an alternative than a strategic function critical to the success of the organization.

\section{THE ROLES OF HRM}

Keep in thought that many features of HRM are additionally duties different branch managers perform, which is what makes these facts important, despite the profession route taken. Most specialists agree on seven principal roles that HRM performs in organizations. One of the most vital function is Development of Workplace Policies. Every business enterprise has policies to make sure equity and continuity inside the organization.

One of the jobs of HRM is to improve the verbiage surrounding these policies. In the improvement of policies, HRM, management, and executives are concerned in the process. For example, the HRM expert will probably apprehend the want for a coverage or an alternate of policy, are searching for opinions on the policy, write the policy, and then speak that coverage to employees. It is key to word right here that HR departments do now not and cannot work alone. Everything they do wants to contain all different departments in the organization.

\section{LITERATURE REVIEW}

Sarma, M., \& Pais, J. (2011). A vital query raised in the literature is whether improvement leads to an all-inclusive monetary system. This paper tries to look at the relationship between economic inclusion and improvement via empirically figuring out U. S. Unique elements that are related with the degree of monetary inclusion. It finds that ranges of human improvement and monetary inclusion in a USA go intently with every other. Among socioeconomic and infrastructure associated factors, income, inequality, literacy, urbanization and bodily infrastructure for connectivity and facts are important. Health of the banking zone does now not appear to have an unambiguous impact on monetary inclusion whereas possession sample does appear to matter. Goel, S., \& Sharma, R. (2017). Finance has continually been regarded as one of the necessary parameter of the boom for any monetary activity. The financial increase of a USA can be enlarged via the use of economic inclusion as a bridge that would facilitate fuller participation by means of weaker sections of the country. Financial inclusion is a device thru which a creating united states of America like India can acquire inclusive boom with the aid of connecting the contribution of weaker or rural populace of the us of a with the principal stream. If there is an effortless get right of entry to of weaker area to the monetary machine of the country, USA can cross in the direction of greater financial growth. In the accessible literature, it has been located that one or the different indicator is absent for exceptional reasons. However, for the reason that every of the indicator is necessary for calculating the extra complete economic inclusion index. The most important goal of this paper is to introduce an index that permits for a normal overview of India in phrases of economic inclusion. The index is calculated the use of three dimensions associated to the dimension of the stages of get admission to and utilization of monetary services. Arora, R. U. (2012). The Australian authorities as phase of its resource program allocates giant dollars to enhance economic inclusion in growing countries. However, this does now not take into account low academic degrees in these countries. The present literature on monetary inclusion additionally treats the difficulty as usually supply-centric and does now not take cognizance of the reality that terrible human improvement and excessive illiteracy stages in creating economies may additionally forestall a massive part of the populace from benefitting from monetary inclusion efforts, due to the fact of low focus and comprehension of the monetary offerings available. This find out about makes use of a detailed three-stage methodological method to have a look at the relationship between economic improvement and human capital in 21 nations of creating Asia. The effects exhibit that a good sized poor relationship exists between 
economic improvement proxied by means of M2/GDP and pupil:teacher ratios and a sturdy advantageous relationship exists between bodily get entry to to banks and anticipated years of schooling. Further, our monetary improvement and academic improvement indices additionally exhibit no clear sample in the chosen countries' economic and instructional development. Arora, R. U. (2012). Most of creating economies have made lately exceptional efforts to formalize economic offerings to the younger technology and a lot of research have been made to see the significance of monetary inclusion in the improvement and boom of economies. Only few of them succeeded in demonstrating the channels that will lead without delay from economic inclusion to growth. While we agree that economic inclusion is an vital trouble in our contemporary economy, few enhancements have been carried out as to unfold economic literacy and monetary intermediaries are nonetheless at the foremost stage restrained to microcredit in many creating countries. This paper research the affect of monetary inclusion on the increase of the economies in creating nations such as the MENA and the BRICS place and strive to discover the channels of transmission between economic literacy, monetary intermediaries and growth. Even although latest findings exhibit that the influence of economic inclusion on monetary overall performance was once a long way beneath expectations and did now not make a contribution to attain some goals, this paper will attempt to introduce new nuances to the findings of this contribution to boom thru direct and oblique contribution and take a look at if monetary inclusion things in phrases of improvement and growth. This paper makes use of a VAR regression in order to quantify the relationship between monetary inclusion in phrases of economic activities, monetary literacy and boom and to find out about its have an impact on the monetary boom in the MENA region. Our Finding confirmed the significance of economic inclusion in this phase of the world alternatively, our statistics are limited.

\section{STUDY OBJECTIVES}

The study objective is to identify the role of human resource management department in enhancing the financial inclusion. Also to what extent the HRM play vital roles for enhancing financial inclusion.

\section{STUDY HYPOTHESIS}

Based on theoretical background and review of previous literature, a conceptual model was developed to show the impact of human resource management roles on financial inclusion.

1. There is no significant level between Age of banks employees and their impact on financial inclusion due to HRM roles.
2. There is no significant level between Gender of banks employees and their impact on financial inclusion due to HRM roles.

3. There is no significant level between Educational Qualification of banks employees and their impact on financial inclusion due to HRM roles.

\section{JUSTIFICATION OF SELECTING THE QUANTITATIVE RESEARCH}

The quantitative approach is provided with suitable research data collection strategy, allowing the collecting of large data amounts from a huge population. The Cronbach' Alpha coefficient is above 0.97 (high reliability). This indicates that each individual item is internally consistent and hence indicates a high degree of reliability.

\section{JUSTIFICATION OF SELECTION THE QUESTIONNAIRE}

The questionnaire started a brief description of the meaning of the main concepts, and it gave instructions on how to answer each section of the questionnaire. A preliminary draft was developed based on an extensive literature review. It includes many questions that are consistent with the research aims. For that reason, the research survey could be described as being comprehensive. It is divided into two parts. The first part includes personal information of the respondents such as gender, Age, Educational qualifications area of profession. The second part includes questions related to financial inclusion.

\section{SAMPLE SIZE}

The sample survey covered five banks of Indian banks. One hundred questionnaires were sent to the five banks.50 questionnaires were returned. Fifty of these were found to be properly filled and had complete information and hence they are considered for my study.

\section{DATA ANALYSIS AND RESULT}

This sample of fifty respondents contains 32 male and 18 female respondents which make-up for 64 and 36 percentage respectively. The largest group of respondents that is $(66 \%)$ with Bachelor degree the smallest group of respondents $(5 \%)$ with up to secondary. $36 \%$ of the respondents are with (31-40) of age group while $8 \%$ more than fifty years of old leaving the remaining into other smaller years of Age group Based on the objectives and hypotheses of the study, the researchers applied the One way ANOVA at $5 \%$ level of significance to test the association between the role of HRM and financial inclusion enhancing. The hypothesizes to be tested is as below.

- H1 state that, "There is no significant level between Age of banks employees and their 
impact on financial inclusion due to HRM roles".

\begin{tabular}{|c|c|c|c|c|c|c|}
\hline \multirow{2}{*}{ ONE AWAY ANOVA } & $\begin{array}{c}\text { Between } \\
\text { Groups }\end{array}$ & .422 & 3 & .141 & .164 & .032 \\
\cline { 5 - 8 } & $\begin{array}{c}\text { Within } \\
\text { Groups } \\
\text { Total }\end{array}$ & 39.505 & 46 & .859 & & \\
\cline { 3 - 6 } & & 39.927 & 49 & & \\
\hline
\end{tabular}

A one-way ANOVA at five percent level of significance is conducted to test the hypothesis. The $\mathrm{P}$-value of 0.32 , which is less than 0.05 and hence null hypothesis is rejected. The ANOVA test proved that, " there is relation between age of banks employees and their impact on financial inclusion enhancement due to HRM roles. This is enable me to conclude that, " the banks employees in different age group confirmed the great HRM roles for enhancing the financial inclusion',

- H2 state that, 'There is no association level between Gender of banks employees and their impact on financial inclusion due to HRM roles"'.
A one-way ANOVA at five percent level of significance is conducted to test the hypothesis. The $\mathrm{P}$-value of 0.048 , which is less than 0.05 and hence null hypothesis is rejected. The ANOVA test proved that, "there is association level between Gender of banks employees and their impact on financial inclusion enhancement due to HRM roles. This is enable me to conclude that, " the banks employees in different Gender group confirmed the great HRM roles for enhancing the financial inclusion'.

- H3 state that, "There is no significant level between Educational qualification of banks employees and their impact on financial inclusion due to HRM roles"'.

\begin{tabular}{|c|c|c|c|c|c|c|}
\hline \multirow{3}{*}{ ONE AWAY ANOVA } & \multirow{3}{*}{$\begin{array}{c}\text { Between } \\
\text { Groups } \\
\text { Within } \\
\text { Groups } \\
\text { Total } \\
\end{array}$} & 1.942 & 2 & .971 & 1.201 & .023 \\
\hline & & 37.985 & 47 & .808 & & \\
\hline & & 39.927 & 49 & & & \\
\hline \multirow{3}{*}{ ONE AWAY ANOVA } & \multirow{3}{*}{$\begin{array}{c}\text { Between } \\
\text { Groups } \\
\text { Within } \\
\text { Groups } \\
\text { Total }\end{array}$} & .198 & 1 & .198 & .240 & .048 \\
\hline & & 39.729 & 48 & .828 & & \\
\hline & & 39.927 & 49 & & & \\
\hline
\end{tabular}

A one-way ANOVA at five percent level of significance is conducted to test the hypothesis. The P-value of 0.023 , which is less than 0.05 and hence null hypothesis is rejected. The ANOVA test proved that, " there is significant level between Gender of

\section{SUGGESTIONS AND CONCLUSIONS}

This paper aims to build a more complete framework of the factors, which influence on the enhancing of financial inclusion in Indian banks. The results of this study clearly show that, " the Indian banks employees strongly conformed the roles of human resource management in enhancing financial inclusion",

This research contributes to the understanding of the role of HRM and financial Inclusion. It describes an integration of human resource management roles and employees' satisfaction to enhance the financial inclusion. I hope that these conclusions will shed some mild for top management and permitting them to make bigger interest to the banks employees and their impact on financial inclusion enhancement due to HRM roles. This is enable me to conclude that, " the banks employees in different Educational levels confirmed the great HRM roles for enhancing the financial inclusion'.

practices of human resource management due to the fact of their significance in enhancing employee's overall performance in the Indian banking sector.

The bank staff should focus on educating people with reference to special advantages of the schemes. "Some of the respondents reacted to the schemes and some respondents are yet to be realize benefits of the schemes". First respondents should understand properly and they, in turn, will intimate their near and dear ones about the benefits they are likely to receive. Word of mouth propagation of the schemes is very important and this should emphasized. A little effort in pushing the schemes further will in all probability reach the shores of success. 


\section{REFERENCE}

1. Shafi, M., \& Medabesh, A. H. (2012). Financial inclusion in developing countries: Evidences from an Indian State. International Business Research, 5(8), 116.

2. Sarma, M., \& Pais, J. (2011). Financial inclusion and development. Journal of international development, 23(5), 613-628.

3. Goel, S., \& Sharma, R. (2017). Developing a financial inclusion index for India. Procedia computer science, 122, 949-956.

4. Arora, R. U. (2012). Financial inclusion and human capital in developing Asia: The Australian connection. Third World Quarterly, 33(1), 177-197.

5. Gretta, S. A. A. B. (2017). Financial inclusion and growth. The Business \& Management Review, 8(4), 434.

6. Rawash, H. N., (2012), "The Impact of Electronic Human Resource Management on Organization's Market Share: An Empirical Study on the Housing Bank for Trade and Finance in Jordan", International Journal of Business and Social Science, 3 (24) [Special Issue - December 2012]: 113-120.

7. Shilpa, V., and Gopal, R., (2011), "The implications of implementing electronic- human resource management (e-hrm) systems in companies", Journal of Information Systems and Communication, 2 (1):10-29.

8. Hadziroh, I., (2013), "Satisfaction towards EHRM in Government Organizations of Malaysia: A Proposed Model Based on Field Theory", Proceeding of the International Conference on Social Science Research, ICSSR 2013 (e-ISBN 978-967- 11768-1-8). 4-5 June 2013, Penang, MALAYSIA. Organized by WorldConferences.net: 1467-1480.

9. https://www.worldbank.org/en/topic/financialincl usion

10. https://www.business-standard.com/about/whatis-financial-inclusion 